\title{
FIXED-BED ADSORPTION OF AQUEOUS VANILLIN ONTO RESIN H103
}

\author{
Rozaimi Abu Samah ${ }^{*}$, Norazwina Zainol ${ }^{1}$, Lai Yee Phang ${ }^{2}$ \\ AND SURAINI ABD-AZIZ ${ }^{2}$ \\ ${ }^{1}$ Faculty of Chemical and Natural Resources Engineering, Universiti Malaysia Pahang, \\ Lebuhraya Tun Razak, 26300 Kuantan, Pahang, Malaysia. \\ ${ }^{2}$ Department of Bioprocess Technology, \\ Faculty of Biotechnology and Biomolecular Sciences, \\ Universiti Putra Malaysia, 43400 UPM Serdang, Selangor, Malaysia. \\ *Corresponding author: rozaimi@ump.edu.my

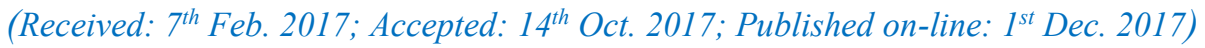

\begin{abstract}
The main objective of this work was to design and model a fixed-bed adsorption column for the adsorption of vanillin from aqueous solution. Three parameters were evaluated for identifying the performance of vanillin adsorption in fixed-bed mode, which were bed height, vanillin initial concentration, and feed flow rate. The maximum adsorption capacity increased more than threefold to $314.96 \mathrm{mg}$ vanillin $/ \mathrm{g}$ resin when the bed height was increased from 5 to $15 \mathrm{~cm}$. Bohart-Adams model and Belter equation were used for designing a fixed-bed column and predicting the performance of the adsorption process. A high value of determination coefficient $\left(R^{2}\right)$ of 0.9672 was obtained for the modelling of vanillin adsorption onto resin H103.
\end{abstract}

ABSTRAK: Tujuan utama kajian ini adalah membentuk dan membina model penyerapan turus-padat bagi penyerapan vanilin daripada larutan akues. Tiga parameter telah dikaji bagi menentukan prestasi penyerapan vanilin dalam mod turus padat, iaitu ketinggian padatan, kepekatan awal vanilin, dan kadar aliran suapan. Peningkatan ketinggian padatan daripada 5 kepada $15 \mathrm{~cm}$ telah meningkatkan kapasiti penyerapan maksimum sebanyak lebih daripada tiga kali ganda kepada $314.96 \mathrm{mg}$ vanilin/g resin. Model persamaan Bohart-Adams dan Belter telah digunakan untuk membentuk kolum turus padat dan prestasi proses penyerapan dijangakan menguna pakai persamaan ini. Nilai pekali penentuan $\left(R^{2}\right)$ yang tinggi pada 0.9672 telah diperoleh daripada model penyerapan vanilin menggunakan resin $\mathrm{H} 103$.

KEYWORDS: adsorption; vanillin; fixed-bed; breakthrough curve

\section{INTRODUCTION}

A sweet odour characteristic is the main driver for vanillin's use in food and beverage industries, as well as perfumes and cosmetics industries. Vanillin (4-hydroxymethoxybenzaldehyde, $\mathrm{C}_{8} \mathrm{H}_{8} \mathrm{O}_{3}, 152.15 \mathrm{~g} / \mathrm{mol}$ ) is produced by a traditional, tedious, and time-consuming process of curing vanilla pods from vanilla plants [1]. It can also be manufactured from several chemicals such as curcumin and eugenol, but the processes deal with high temperatures and pressures [2]. In addition, the waste products from the chemical reactions may impose problems on the environment [3]. Moving forward, biotechnology offers ways of producing vanillin at ambient conditions by the action of microorganisms and/or enzymes on abundant sources of raw material such as biomass. 
Several components from biomass are identified as potential sources for the production of vanillin such as ferulic acid, vanillic acid, and lignin [4]

Due to its phenolic and aldehyde functional groups in its molecular structure, vanillin can be toxic to the producing microorganisms. Therefore, a proper separation technique is needed to intermittently remove the vanillin as it is being produced. Membrane separation [5-7], extraction [8], and crystallisation [9] are among the possible separation techniques to recover vanillin directly from the production vessel. In addition, adsorption has gained a lot of interest among researchers to separate vanillin using several types of polymeric adsorbents such as Sephabeads SP206, NKA-2, S-8, and DM11 [10-17]. An anisolemodified hyper-cross-linked polystyrene HJ-108 [15] and Sepabeads SP700 [17] are among the recent reported polymeric resins to be used for vanillin adsorption in batch and fixed-bed modes.

Compared to the batch adsorption process, fixed-bed mode offers a greater insight into the adsorption behaviour. The adsorbent is packed in a column and solution is passed through the adsorbent bed. The packed column can be attached to an automatic delivery system or let gravity perform all the work. From the process, the most studied part is the breakthrough analysis. The solution is pumped through the packed column for continuous adsorption, until a point where the adsorbent is saturated with the target molecule. During the continuous feed, the concentration of target molecule is monitored in the effluent. A plot of the ratio of effluent to feed concentration $\left(C_{t} / C_{0}\right)$ versus time $(t)$ explains the behaviour of the adsorption process in fixed-bed mode, which is known as a breakthrough curve. A breakthrough point is where an acceptable amount of target molecule appears in the effluent that could be discarded $\left(t_{b}-\right.$ breakthrough time, $C_{b}-$ breakthrough concentration). The breakthrough point value depends on any particular application. Normally, the range is $1 \%$ to $10 \%$ of the feed concentration [18], but there are often cases where the acceptable limit is taken as 5\% [19].

One of the advantages of utilising the fixed-bed mode is a large volume of the solution can be introduced to the adsorbent, but feeding the solution beyond the breakthrough point would result in loss of the target molecule. On the other hand, feeding a small volume of the solution would result in incomplete utilisation of the adsorbent's capacity in the column [18]. This breakthrough analysis can determine the performance of a fixed-bed, and at the same time, a minimum number of experiments can be done so that the prediction of a larger scale fixed-bed adsorption could be done as well [20-23]. For all the advantages of the fixed-bed mode, this work was executed to evaluate the vanillin adsorption onto resin H103 in a fixed-bed mode. The use of resin H103 has been reported earlier for the adsorption of vanillin in batch mode [24].

\section{METHODOLOGY}

\subsection{Materials Preparation}

Resin H103 was purchased from Shanghai Sunny Scientific Collaboration Co. (Ltd). Vanillin used in this work was purchased from Acros Organics (Belgium). Fixed-bed column adsorption studies were performed in Tricon columns supplied by GE Healthcare (i.d. $10 \mathrm{~mm}$ ). The column was packed with resin $\mathrm{H} 103$ at certain heights. Prior to packing, the resin was soaked in absolute methanol and subsequently filtered and washed with distilled water [25]. All experiments were performed at room temperature with an ÄKTAexplorer 100 system (Amersham Pharmacia Biotech). 


\subsection{Scale-Up Analysis for Vanillin Adsorption}

The general methods were based on a previous work with slight modifications [26]. Three bed heights were used in this work: 5,10 , and $15 \mathrm{~cm}$. The initial flow rate used was $5 \mathrm{~mL} / \mathrm{min}$ and the vanillin solution was prepared at $1,000 \mathrm{mg} / \mathrm{L}[12,27]$. The effluents from the column were collected at fixed time intervals of 6 min and analysed offline using a UV-visible spectrophotometer at $280 \mathrm{~nm}$ [28].

The breakthrough curve analysis was done by varying any one of the parameters. In this work, by fixing the bed height at $10 \mathrm{~cm}$, two other parameters were varied, which were the flow rate $(10 \mathrm{~mL} / \mathrm{min})$ and vanillin initial concentration $(900 \mathrm{mg} / \mathrm{L})$. Subsequently, a breakthrough curve was plotted as the ratio of effluent vanillin concentration to vanillin initial concentration $\left(C_{t} / C_{0}\right)$ versus time $(t)$.

\subsection{Fixed-Bed Column Design}

A Bohart-Adams model was used in the design of a fixed-bed vanillin adsorption column, as shown in Eq. (1).

$$
\ln \left(\frac{C_{0}}{C_{b}}-1\right)=\ln \left(\exp \frac{k N Z}{V}-1\right)-k C_{0} t
$$

where, $C_{0}$ is the initial vanillin concentration $(\mathrm{mg} / \mathrm{L}), C_{b}$ is the breakthrough vanillin concentration $(\mathrm{mg} / \mathrm{L}), k$ is the rate constant $(\mathrm{g} / \mathrm{mg} \cdot \mathrm{h}), N$ is the adsorption capacity $(\mathrm{mg} / \mathrm{g})$, $Z$ is the bed height $(\mathrm{cm}), V$ is the linear velocity $(\mathrm{cm} / \mathrm{min})$, and $t$ is the breakthrough time (min) $[26,29]$.

For the determination of adsorption capacity $(N)$ and rate constant $(k)$, the model was then linearised, as shown in Eq. (2).

$$
t=\frac{N Z}{C_{0} V}-\frac{1}{k C_{0}} \ln \left(\frac{C_{0}}{C_{b}}-1\right)
$$

where, the slope $(m)$ is $\frac{N}{C_{0} V}$, and the intercept $(c)$ is $-\frac{1}{k c_{0}} \ln \left(\frac{c_{0}}{c_{b}}-1\right)$. A plot of time versus bed height was used to determine the adsorption capacity and rate constant.

At $t=0$, Eq. (2) was used to determine the minimum bed height of resin $\mathrm{H} 103$ to give an effluent concentration of $C_{b}$, or critical bed height $\left(Z_{0}\right)$, as shown in Eq. (3).

$$
Z_{0}=\frac{V}{k N_{0}} \ln \left(\frac{C_{0}}{C_{b}}-1\right)
$$

For designing a new fixed-bed adsorption column based on a different vanillin initial concentration, the slope and intercept parameters in the linearised plot were determined by the following relationships in Equations (4) and (5) [26].

$$
\begin{aligned}
& m_{2}=m_{1} \frac{C_{1}}{C_{2}} \\
& c_{2}=c_{1}\left(\frac{C_{1}}{C_{2}}\right)\left[\frac{\ln \left(C_{2}-1\right)}{\ln \left(C_{1}-1\right)}\right]
\end{aligned}
$$

where $m_{1}$ and $m_{2}$ are the slope parameters for the original and new vanillin initial concentrations, respectively, and $C_{1}$ and $C_{2}$ are the original and new vanillin initial concentrations, respectively. 
Similarly, for designing a new fixed-bed adsorption column based on a different feed flow rates, the slope and intercept parameters in the linearised plot were determined by Eq. (6) $[26]$.

$$
m_{2}=m_{1} \frac{Q_{1}}{Q_{2}}
$$

where $Q_{1}$ and $Q_{2}$ are the original and new feed flow rates, respectively. The intercept value change is assumed insignificant with respect to different feed flow rates [29].

\subsection{Modelling of Breakthrough Curve}

The breakthrough curve for fixed-bed vanillin adsorption onto resin H103 was modelled based on a two-parameter model [30], as shown in Eq. (7).

$$
\frac{C_{E}}{C_{F}}=\frac{1}{2}\left[1+\operatorname{erf}\left(\frac{t-t_{0}}{\sqrt{2} \sigma t_{0}}\right)\right]
$$

where $C_{E}$ and $C_{F}$ are the vanillin concentrations in the effluent and feed, respectively, $t_{0}$ is the time at which the vanillin concentration in the effluent is half in the feed (determined experimentally), $\operatorname{erf}(x)$ is the error function of $x$, and $\sigma$ represents the standard deviation, a measure of the slope of the curve (determined experimentally). The experimental data were calculated using the above equation, and plotted on the same plot of $C_{t} / C_{0}$ versus time of the experimental data. The experiments were done with the bed height of $10 \mathrm{~cm}$, volumetric flow rate of $5 \mathrm{~mL} / \mathrm{min}$, and initial vanillin concentration of $900 \mathrm{mg} / \mathrm{L}$. Coefficient of determination $\left(R^{2}\right)$ was determined to verify whether the model obtained was acceptable or not.

\section{RESULTS AND DISCUSSION}

\subsection{Breakthrough Curve Analysis for Fixed-bed Adsorption}

Three parameters are usually varied in fixed-bed adsorption, namely bed height, solute initial concentration, and feed flow rate. By varying these three factors, the behaviour of the adsorption in the fixed-bed column can be determined. In this work, only bed height was varied to determine the dynamic behaviour of vanillin adsorption onto resin $\mathrm{H} 103$ that was packed in a column.

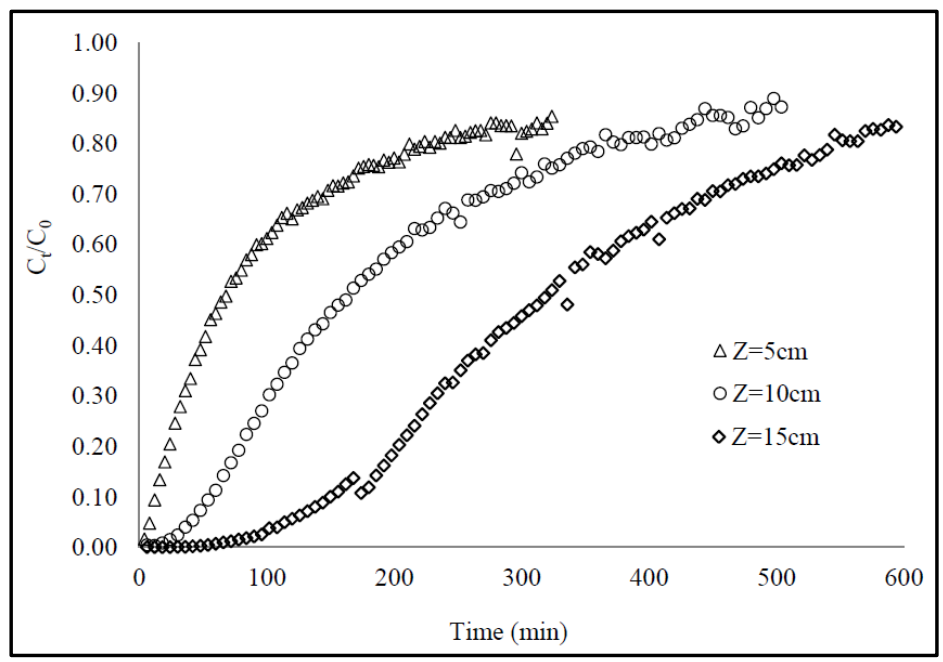

Fig. 1: The effect of bed height on breakthrough curves for vanillin adsorption onto resin $\mathrm{H} 103$. 
Fig. 1 shows the effect of bed height on the breakthrough curves for vanillin adsorption onto resin H103. The breakthrough time decreased considerably with the increasing bed height. For $15-\mathrm{cm}$ bed height, the exit concentration of vanillin increased very slowly at the beginning of the process, as compared to the other two bed heights. For $5-\mathrm{cm}$ bed height, the vanillin was detected in the quite early stage of the feeding process. For a breakthrough point of $10 \%$, the time taken in a $15-\mathrm{cm}$ bed height was $150 \mathrm{~min}$. It was reduced to $60 \mathrm{~min}$ for $10-\mathrm{cm}$ bed height and roughly $12 \mathrm{~min}$ for $5-\mathrm{cm}$ bed height. In the actual separation process using this mode, it would be beneficial to stop the feeding of the sample when the effluent reaches this breakthrough point, and the adsorbed solutes are eluted out from the column. After that, the adsorbent is normally regenerated for the next cycle of adsorption process, or the spent adsorbent is discarded [31].

The steepness of the curve determines the utilisation of the packed adsorbent. For a good and efficient fixed-bed, a very steep breakthrough curve would be observed, which means that most of the adsorbent capacity is utilised for the adsorption process [19]. In this work, the steepness of the curves obtained was considered as gradual, and this shows that the fixed-bed columns were of medium performance, as shown in Table 1 that the fraction of total bed was only used up to 0.417 . In a published work, polymeric adsorbent Sephabeads SP206 gave a good utilisation of the adsorbent in a fixed-bed mode for the recovery of vanillin by obtaining steep breakthrough curves [12]. A similar trend was also reported on the effect of bed height in the adsorption of gallic acid onto activated carbon cloth and activated carbon I-60 [26].

Table 1: The effect of bed height towards breakthrough capacity

\begin{tabular}{cccccc}
\hline $\begin{array}{c}\text { Bed } \\
\text { height } \\
\text { (cm) }\end{array}$ & $\begin{array}{c}\text { Amount of } \\
\text { adsorbent } \\
\text { (g) }\end{array}$ & $\begin{array}{c}\text { Breakthrough } \\
\text { time (min) }\end{array}$ & $\begin{array}{c}\text { Breakthrough } \\
\text { capacity } \\
\text { (mg vanillin/g } \\
\text { adsorbent) }\end{array}$ & $\begin{array}{c}\text { Fraction } \\
\text { used up to } \\
\text { breakpoint }\end{array}$ & $\begin{array}{c}\text { Maximum } \\
\text { adsorption } \\
\text { capacity } \\
\text { (mg/g) }\end{array}$ \\
\hline 5 & 2.5 & 12 & 10.43 & 0.107 & 96.813 \\
10 & 5.0 & 60 & 51.99 & 0.268 & 194.125 \\
15 & 7.5 & 150 & 131.44 & 0.417 & 314.960 \\
\hline
\end{tabular}

In a fixed-bed column of resin H103, an increase of its bed height caused the vanillin to have more time to be in equilibrium with the resin. This resulted into an increased time observed to detect vanillin in the effluent, hence the longer breakthrough time, as shown in Table $1[32,33]$. It may be because the increase in bed height gives more time for the solutes to have contact with the adsorbent, which results into higher removal capacity and lower solute concentration in the effluent. Besides, at larger bed height, more effective surface area of adsorbent is available that offers more active sites for adsorption. For this work, when the bed height was increased threefold, the breakthrough capacity of the fixedbed adsorption increased more than tenfold from 10.43 to $131.44 \mathrm{mg}$ vanillin/g adsorbent. The maximum adsorption capacity also increased approximately threefold.

\subsection{Designing Fixed-bed Column for Vanillin Adsorption}

A Bohart-Adams model was used on the assumption that the adsorption process is continuous where equilibrium is not attained instantaneously [34]. This model was used for designing a fixed-bed column, by varying any one of the parameters. The model explains the performance of a continuous column via Eq. (1). The equation was rearranged to obtain a linearised plot of service time versus bed height, as shown in Fig. 2. 


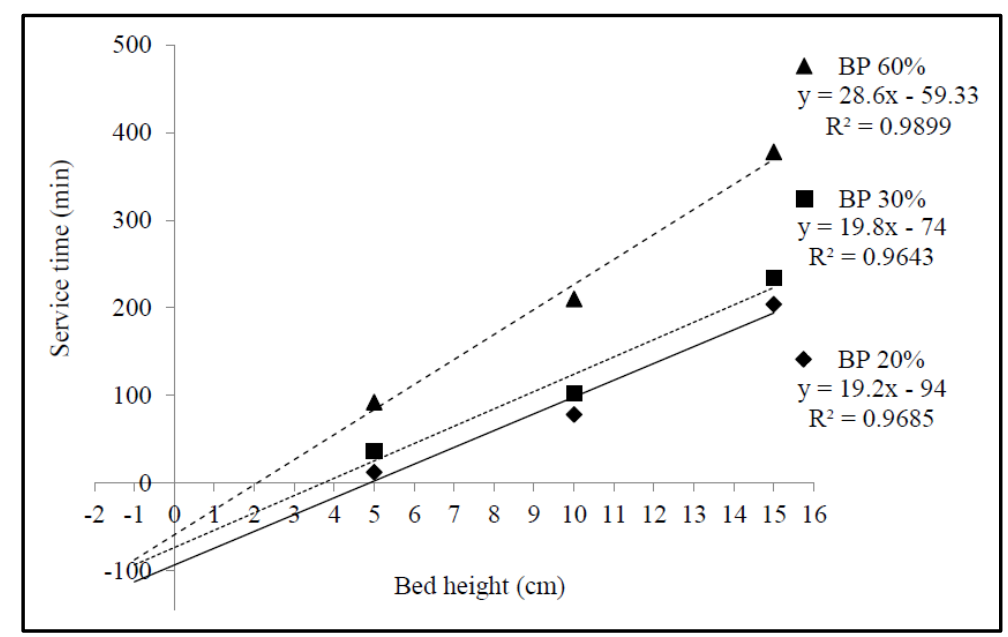

Fig. 2: Bohart-Adams model for different breakthrough points (BP) at different bed heights, constant flow rate $(5 \mathrm{~mL} / \mathrm{min})$, and constant vanillin initial concentration $(1,000 \mathrm{mg} / \mathrm{L})$.

Under a constant condition of flow rate $(5 \mathrm{~mL} / \mathrm{min})$ and vanillin initial concentration $(1,000 \mathrm{mg} / \mathrm{L})$, three different breakthrough points $(20 \%, 30 \%$, and $60 \%)$ were utilised for this model analysis. The slopes and intercepts of each linear line were used to obtain the dynamic adsorptive capacity and adsorption rate constant, as shown in Table 2.

Table 2: Bohart-Adams model constants for the vanillin adsorption onto fixed-bed resin $\mathrm{H} 103$.

\begin{tabular}{|c|c|c|c|c|c|c|c|}
\hline $\begin{array}{c}\text { Breakpoint } \\
\text { (\%) }\end{array}$ & $\begin{array}{c}\text { Bed } \\
\text { height } \\
(\mathrm{cm})\end{array}$ & $\begin{array}{l}\text { Service } \\
\text { time } \\
(\mathrm{min})\end{array}$ & $\begin{array}{c}\text { Slope, } \\
m \\
(\mathrm{~min} / \mathrm{cm})\end{array}$ & $\begin{array}{l}\text { Adsorption } \\
\text { capacity, } N \\
\quad(\mathrm{mg} / \mathrm{g})\end{array}$ & $\begin{array}{c}\text { Intercept, } \\
c \\
\text { (min) }\end{array}$ & $\begin{array}{l}\text { Adsorption } \\
\text { rate } \\
\text { constant, } k \\
(\mathrm{~g} / \mathrm{mg} \cdot \mathrm{h})\end{array}$ & $\begin{array}{c}\text { Critical } \\
\text { depth, } Z Z_{0} \\
\text { (cm) }\end{array}$ \\
\hline \multirow{3}{*}{20} & 5 & 12 & \multirow{3}{*}{19.2} & \multirow{3}{*}{116.41} & \multirow{3}{*}{-94} & \multirow{3}{*}{0.929} & \multirow{3}{*}{4.896} \\
\hline & 10 & 78 & & & & & \\
\hline & 15 & 204 & & & & & \\
\hline \multirow{3}{*}{30} & 5 & 36 & \multirow{3}{*}{19.8} & \multirow{3}{*}{120.05} & \multirow{3}{*}{-74} & \multirow{3}{*}{0.721} & \multirow{3}{*}{3.737} \\
\hline & 10 & 102 & & & & & \\
\hline & 15 & 234 & & & & & \\
\hline \multirow{3}{*}{60} & 5 & 92 & \multirow{3}{*}{28.6} & \multirow{3}{*}{173.40} & \multirow{3}{*}{-59.33} & \multirow{3}{*}{$\sim 0$} & \multirow{3}{*}{2.075} \\
\hline & 10 & 210 & & & & & \\
\hline & 15 & 378 & & & & & \\
\hline
\end{tabular}

The adsorptive capacity increased according to the increment of the breakthrough point. This reflects the amount of vanillin adsorbed onto the resin. In the Bohart-Adams model, this value is used to predict the performance of the fixed-bed adsorption processes with different parameters. Meanwhile, critical depth denotes a minimum height sufficient for the breakthrough concentration. Critical depths $\left(Z_{0}\right)$ of $4.9,3.7$, and $2.1 \mathrm{~cm}$ were obtained from the calculation and they were in agreement with the graphical determination shown in Fig. 2 (by extrapolating the linear lines).

Values in Table 2 were used in predicting the performance of the fixed-bed adsorption of vanillin onto resin $\mathrm{H} 103$ at different vanillin initial concentrations and feed flow rates. The method applied was based on Eq. (1). For a new vanillin concentration, it was possible to predict the performance of the fixed-bed column using the slope and 
intercept parameters in the linearised plot (Fig. 2). The prediction of new slope $\left(m_{2}\right)$ and intercept $\left(c_{2}\right)$ were made using Eqs. (4) and (5), respectively.

Table 3 lists the new slopes and intercepts and the predicted and observed times that occurred for fixed-bed adsorption with a new vanillin concentration of $900 \mathrm{mg} / \mathrm{L}$. The predicted times for three different breakthrough points of $20 \%, 30 \%$, and $60 \%$ were 110 , 139, and $253 \mathrm{~min}$, respectively. Meanwhile, the observed times obtained through experiments were 108, 132, and $198 \mathrm{~min}$, respectively. The times taken for each experimental breakthrough using $900 \mathrm{mg} / \mathrm{L}$ of vanillin feed concentration were also compared to the values of $1,000 \mathrm{mg} / \mathrm{L}$ of vanillin. It was proven that a lower feed concentration produced a longer breakthrough time because given the same amount of adsorbent resin, it took a longer time for the total adsorbent resin to be saturated with vanillin.

Table 3: Predicted breakthrough times using a Bohart-Adams constant for new vanillin initial concentration $(900 \mathrm{mg} / \mathrm{L})$. Flow rate and bed height were kept constant at $5 \mathrm{~mL} / \mathrm{min}$ and $10 \mathrm{~cm}$, respectively.

\begin{tabular}{cccccc}
\hline $\begin{array}{c}\text { Breakthrough } \\
\text { point }(\mathbf{\%})\end{array}$ & $\begin{array}{c}\text { Slope, } \boldsymbol{m}_{\mathbf{2}} \\
(\mathbf{m i n} / \mathbf{c m})\end{array}$ & $\begin{array}{c}\text { Intercept, } \boldsymbol{c}_{\mathbf{2}} \\
\mathbf{( \mathbf { m i n } )}\end{array}$ & $\begin{array}{c}\text { Predicted time } \\
(\mathbf{m i n})\end{array}$ & $\begin{array}{c}\text { Observed time } \\
(\mathbf{m i n})\end{array}$ & $\begin{array}{c}\text { Observed time } \\
\text { for } \mathbf{1 , 0 0 0} \mathbf{~ m g} / \mathbf{L}\end{array}$ \\
\hline 20 & 21.33 & -102.85 & 110 & 108 & 78 \\
30 & 22 & -80.97 & 139 & 132 & 102 \\
60 & 31.78 & -64.92 & 253 & 198 & 210 \\
\hline
\end{tabular}

A small variation in the calculated and experimental values was observed in the fixedbed adsorption of gallic acid [26]. A duration of $1.25 \mathrm{~h}$ experimental breakthrough time at $10 \%$ breakthrough was obtained for the change of feed concentration from 50 to $100 \mathrm{mg} / \mathrm{L}$ of gallic acid, compared to $1.66 \mathrm{~h}$ of the predicted or calculated breakthrough time. In another work, $20 \mathrm{~min}$ was the observed breakthrough time at $20 \%$ breakthrough, compared to $22.3 \mathrm{~min}$, when the inlet concentration of $\mathrm{Cr}(\mathrm{VI})$ was reduced from 10 to 5 $\mathrm{mg} / \mathrm{L}$ [35]. Similar results were obtained for the adsorption of textile dye Blue 86 using a carbon-alumina composite [33]. Therefore, it can be concluded that the design parameters can be utilised to predict or design the column adsorption for other feed concentrations.

Table 4: Predicted breakthrough times using Bohart-Adams constant for new flow rate $(10 \mathrm{~mL} / \mathrm{min})$. Vanillin initial concentration and bed height were kept constant at $1,000 \mathrm{mg} / \mathrm{mL}$ and $10 \mathrm{~cm}$, respectively.

\begin{tabular}{ccccc}
\hline $\begin{array}{c}\text { Breakthrough } \\
\text { point } \mathbf{( \% )}\end{array}$ & $\begin{array}{c}\text { Slope, } \boldsymbol{m}_{\mathbf{2}} \\
(\mathbf{m i n} / \mathbf{c m})\end{array}$ & $\begin{array}{c}\text { Predicted time } \\
(\mathbf{m i n})\end{array}$ & $\begin{array}{c}\text { Observed } \\
\text { time (min) }\end{array}$ & $\begin{array}{c}\text { Observed time } \\
\text { for } \mathbf{5} \mathbf{~} \mathbf{m L} / \mathbf{m i n}\end{array}$ \\
\hline 20 & 9.6 & 50 & 66 & 204 \\
30 & 9.9 & 75 & 84 & 234 \\
60 & 14.3 & 155 & 144 & 378 \\
\hline
\end{tabular}

Table 4 lists the predicted and observed times that occurred for the new feed flow rate of $10 \mathrm{~mL} / \mathrm{min}$. The breakthrough points greatly reduced when the flow rate was doubled. When the flow rate was increased from 5 to $10 \mathrm{~mL} / \mathrm{min}$, it only took $66 \mathrm{~min}$ to reach the $20 \%$ breakthrough point, as compared to $204 \mathrm{~min}$. It was also obvious that the differences between the predicted and observed times were small. It was observed that 66,84 , and 144 
min were the points of breakthrough for $20 \%, 30 \%$, and $60 \%$, respectively, while the calculated points were calculated to be 50,75 , and $155 \mathrm{~min}$. The possible reason for the shorter breakthrough caused by increased feed flow rate might be due to the lesser contact time between vanillin and resin $\mathrm{H} 103$, or shorter residence time $[33,36]$.

Similarly, in the adsorption of $\mathrm{Cr}(\mathrm{VI})$, small differences were also observed, which were $7 \mathrm{~min}$ for $20 \%$ breakthrough, compared to the calculated time of 6 min [35]. This shows that Bohart-Adams model applied to the current data indicated good agreement between both calculated and experimental values. This analysis also enables the researchers to predict the performance of a given fixed-bed adsorption column without having to perform any further and extensive experiments for different process parameters [37]. The possible reason for the shorter breakthrough caused by increased feed flow rate might be due to the lesser contact time between vanillin and resin H103, or shorter residence time $[33,36]$.

Another approach in predicting the breakthrough curve was made using a simple twoparameter model. Figure 3 shows the comparison between the experimental data for a fixed-bed adsorption and the model using Eq. (7). The experiment was performed using a bed height of $10 \mathrm{~cm}$, flow rate of $5 \mathrm{~mL} / \mathrm{min}$, and new vanillin initial concentration of 900 $\mathrm{mg} / \mathrm{L}$. It was obvious that the simple two-parameter model could also predict the behaviour of vanillin adsorption onto resin $\mathrm{H} 103$ at different parameters, with a determination coefficient $\left(R^{2}\right)$ value of 0.9672. Compared to the Bohart-Adams model, this approach is considered to be a simpler method because a minimum of one experiment is needed for the prediction of the fixed-bed adsorption behaviour. The standard deviation value $(\sigma)$ obtained from the modelling can be used for the determination of the changes in the breakthrough curve for a new fixed-bed adsorption column at different lengths and feed flow rates [30]. This approach was also tested and improved for the modelling of the adsorption of cadmium ions by marine algae [38], Ascopyllum nodosum [39], and the adsorption of copper ions by polyvinyl formal-immobilised Rhizopus arrhizus and native Mucor miehei [40]. Based on the model obtained, the saturation bed capacity, or maximum adsorption capacity, was determined to be $165.9 \mathrm{mg}$ of vanillin/g of adsorbent for the bed height of $10 \mathrm{~cm}$.

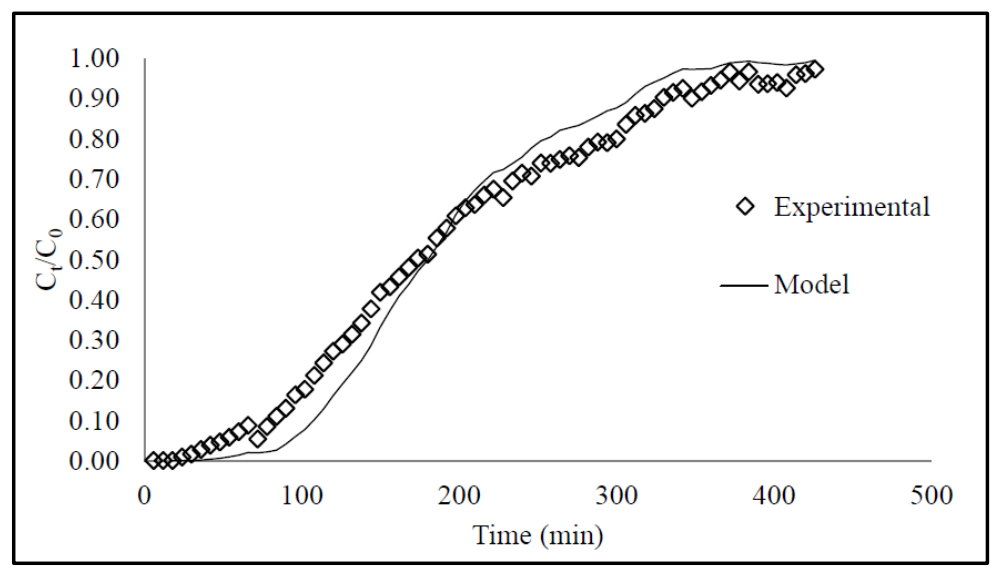

Fig. 3: Mathematical modelling using Belter equation.

The experiments were done with a bed height $(Z)$ of $10 \mathrm{~cm}$,

volumetric flow rate $(Q)$ of $5 \mathrm{~mL} / \mathrm{min}$, and

initial vanillin concentration $\left(C_{0}\right)$ of $900 \mathrm{mg} / \mathrm{L}$. 


\section{CONCLUSION}

The vanillin adsorption from aqueous solution in fixed-bed mode was successfully performed and modelled. Fixed-bed mode can be utilised to predict the behaviour of the adsorption of vanillin onto resin H103. A Bohart-Adams model and a Belter equation were used to perform scaling analysis of a fixed-bed adsorption. The dynamic adsorption capacities at $10 \%$ breakthrough point were experimentally determined to be 96.813 , 194.125 , and $314.960 \mathrm{mg}$ of vanillin/g of adsorbent for different bed heights of 5, 10, and $15 \mathrm{~cm}$, respectively. For comparison, the modelled maximum adsorption capacity for a $10-$ $\mathrm{cm}$ bed height obtained was slightly different at the value of $165.9 \mathrm{mg}$ of vanillin/g of adsorbent.

\section{ACKNOWLEDGEMENT}

The authors thank University Research Grant Scheme, Universiti Putra Malaysia, and Academic Training Scheme for Institutions of Higher Education (SLAI), Malaysia, for financial supports throughout this research project

\section{REFERENCES}

[1] Reineccius G. (2005) Flavoring Materials, Flavor Chemistry and Technology, Second Edition, CRC Press, Florida, pp. 203-259.

[2] Dolfini JE, Glinka J, Bosch AC. (1990) Patent No. 4,927,805. Washington: USPTO.

[3] Vidal JP. (2008) Vanillin, Kirk-Othmer Food and Feed Technology, John Wiley \& Sons, New Jersey, pp. 526-538.

[4] Walton NJ, Narbad A, Faulds C, Williamson G. (2000) Novel approaches to the biosynthesis of vanillin, Current Opinion in Biotechnology, 11(5):490-496.

[5] Brazinha C, Barbosa DS, Crespo JG. (2011) Sustainable recovery of pure natural vanillin from fermentation media in a single pervaporation step, Green Chemistry, 13(8): 2197-2203.

[6] Wu YT, Feng M, Ding WW, Tang XY, Zhong YH, Xiao ZY. (2008) Preparation of vanillin by bioconversion in a silicon rubber membrane bioreactor, Biochemical Engineering Journal, 41(2):193-197.

[7] Sciubba L, Di Gioia D, Fava F, Gostoli C. (2009) Membrane-based solvent extraction of vanillin in hollow fiber contactors, Desalination, 241(1):357-364.

[8] de Brito Cardoso G, Mourão T, Pereira FM, Freire MG, Fricks AT, Soares CMF, Lima ÁS. (2013) Aqueous two-phase systems based on acetonitrile and carbohydrates and their application to the extraction of vanillin, Separation and Purification Technology, 104:106113.

[9] Taber DF, Patel S, Hambleton TM, Winkel EE. (2007) Vanillin synthesis from 4hydroxybenzaldehyde, Journal of Chemical Education, 84(7):1158.

[10] Li R, Jiang Z, Mao L, Shen H. (1998) Adsorbed resin phase spectrophotometric determination of vanillin or/and its derivatives, Talanta, 47(5):1121-1127.

[11] Zhao LQ, Sun ZH, Zheng P, He JY. (2006) Biotransformation of isoeugenol to vanillin by Bacillus fusiformis CGMCC1347 with the addition of resin HD-8, Process Biochemistry, 41(7):1673-1676.

[12] Zabkova M, Otero M, Minceva M, Zabka M, Rodrigues AE. (2006) Separation of synthetic vanillin at different $\mathrm{pH}$ onto polymeric adsorbent Sephabeads SP206, Chemical Engineering and Processing: Process Intensification, 45(7): 598-607.

[13] Hua D, Ma C, Song L, Lin S, Zhang Z, Deng Z, Xu P. (2007) Enhanced vanillin production from ferulic acid using adsorbent resin, Applied Microbiology and Biotechnology, 74(4):783-790.

[14] Wang Z, Chen K, Li J, Wang Q, Guo J. (2010) Separation of vanillin and syringaldehyde from oxygen delignification spent liquor by macroporous resin adsorption, CLEAN - Soil, Air, Water, 38(11):1074-1079. 
[15] Jin X, Huang J. (2012) Adsorption of vanillin by an anisole-modified hyper-cross-linked polystyrene resin from aqueous solution: Equilibrium, kinetics, and dynamics, Advances in Polymer Technology, 32:1-10.

[16] Xiao GQ, Long LP, Wang JL. (2012) Synthesis of the water-compatible $p$-acetaminophen resin and its adsorption performances for vanillin in aqueous solution, Chinese Chemical Letters, 23(1):123-126.

[17] Mota MIF, Pinto PCR, Loureiro JM, Rodrigues AE. (2016) Adsorption of vanillin and syringaldehyde onto a macroporous polymeric resin, Chemical Engineering Journal, 288:869-879.

[18] Ghosh R. (2006) Principles Of Bioseparations Engineering, World Scientific, Singapore.

[19] Geankoplis CJ. (2003) Transport Processes and Separation Process Principles (Includes Unit Operations), Fourth ed., Prentice Hall, New Jersey.

[20] Krings U, Berger R. (1995) Porous polymers for fixed bed adsorption of aroma compounds in fermentation processes, Biotechnology Techniques, 9(1):19-24.

[21] Couteau D, Mathaly P. (1998) Fixed-bed purification of ferulic acid from sugar-beet pulp using activated carbon: Optimization studies, Bioresource Technology, 64(1):17-25.

[22] Singh TS, Pant KK. (2006) Experimental and modelling studies on fixed bed adsorption of As(III) ions from aqueous solution, Separation and Purification Technology, 48(3):288-296.

[23] Adak A, Bandyopadhyay M, Pal A. (2006) Fixed bed column study for the removal of crystal violet (C. I. Basic Violet 3) dye from aquatic environment by surfactant-modified alumina, Dyes and Pigments, 69(3):245-251.

[24] Samah RA, Zainol N, Yee PL, Pawing CM, Abd-Aziz S. (2013) Adsorption of Vanillin using Macroporous Resin H103, Adsorption Science \& Technology, 31(7):599-610.

[25] Lee E-G, Yoon S-H, Das A, Lee S-H, Li C, Kim J-Y, Choi M-S, Oh D-K, Kim S-W. (2009) Directing vanillin production from ferulic acid by increased acetyl-CoA consumption in recombinant Escherichia coli, Biotechnology and Bioengineering, 102(1):200-208.

[26] Goyal M, Dhawan R, Bhagat M. (2010) Adsorption of gallic acid from aqueous solution using fixed bed activated carbon columns, Separation Science and Technology, 45(9):12651274.

[27] Zhang QF, Jiang ZT, Gao HJ, Li R. (2008) Recovery of vanillin from aqueous solutions using macroporous adsorption resins, European Food Research and Technology, 226(3):377-383.

[28] Huesgen AG. (2011) Analysis of natural and artificial vanilla preparations, Agilent Application Note, pp. 1-12.

[29] Eckenfelder WW. (2000) Industrial Water Pollution Control, McGraw-Hill, New York.

[30] Belter PA, Cussler EL, Hu WS. (1988) Bioseparations: Downstream Processing for Biotechnology, Wiley, New York.

[31] Seader JD, Henley EJ, Roper DK. (2010) Separation Process Principles, John Wiley \& Sons, New Jersey.

[32] Chen N, Zhang Z, Feng C, Li M, Chen R, Sugiura N. (2011) Investigations on the batch and fixed-bed column performance of fluoride adsorption by Kanuma mud, Desalination, 268(13):76-82.

[33] Dutta M, Basu JK, FaraZ H, Gautam N, Kumar A. (2012) Fixed bed column study of textile dye, Direct Blue 86 by using a composite adsorbent, Archives of Applied Science Research, 4(2):882-891.

[34] Bohart GS, Adams EQ. (1920) Some aspects of the behavior of charcoal with respect to chlorine, Journal of the American Chemical Society, 42(3):523-544.

[35] Kiran B, Kaushik A. (2008) Cyanobacterial biosorption of Cr(VI): Application of two parameter and Bohart Adams models for batch and column studies, Chemical Engineering Journal, 144(3):391-399.

[36] Ko DCK, Porter JF, McKay G. (2000) Optimised correlations for the fixed-bed adsorption of metal ions on bone char, Chemical Engineering Science, 55(23):5819-5829.

[37] Chu KH, Kim EY, Feng X. (2011) Batch kinetics of metal biosorption: Application of the Bohart-Adams rate law, Separation Science and Technology, 46(10):1591-1601. 
[38] Chu KH. (2004) Improved fixed bed models for metal biosorption, Chemical Engineering Journal, 97(2-3):233-239.

[39] Volesky B, Prasetyo I. (1994) Cadmium removal in a biosorption column, Biotechnology and Bioengineering, 43(11):1010-1015.

[40] Brady JM, Tobin JM, Roux J-C. (1999) Continuous fixed bed biosorption of $\mathrm{Cu}^{2+}$ ions: application of a simple two parameter mathematical model, Journal of Chemical Technology \& Biotechnology, 74(1):71-77. 